\title{
Indomethacin Promotes Adipogenesis of Mesenchymal Stem Cells Through a Cyclooxygenase Independent Mechanism
}

\author{
Maya Styner*, Buer Sen, Zhihui Xie, Natasha Case, and Janet Rubin \\ Department of Medicine, University of North Carolina, Chapel Hill, North Carolina 27599
}

\section{Abstract}

Regulation of mesenchymal stem cell (MSC) lineage selection is important for the generation of bone mass. Inhibition of cyclooxygenase-2 (COX2) may increase adipogenesis at the cost of decreasing osteoprogenitor output. Here we investigated the role of COX2 and its products during MSC differentiation. Indomethacin stimulated adipogenesis (increased aP2, adiponectin and lipid droplets) of CH310T1/2 stem cells as well as marrow-derived MSCs to a degree similar to the PPAR $\gamma 2$ ligand, rosiglitazone. Unlike rosiglitazone, indomethacin significantly upregulated PPAR $\gamma 2$ expression. Indomethacin and the COX2 specific inhibitor celecoxib suppressed PGE2 production, but celecoxib did not induce adipogenesis. As well, addition of PGE2 failed to reverse indomethacin induced adipogenesis, indicating that indomethacin's effects were prostaglandin independent. In MSCs over-expressing PPAR $\gamma 2$ and RXRa, indomethacin did not increase PPAR-induced transcription, while rosiglitazone and 15d-PGJ2 did (1.7- and 1.3-fold, respectively, $P<0.001$ ). We considered whether indomethacin might directly affect C/EBP $\beta$ proximally to PPAR $\gamma 2$ induction. Indomethacin significantly increased C/EBP $\beta$ expression and protein within $24 \mathrm{~h}$ of addition. These results indicate that indomethacin promotes adipogenesis by increasing C/EBP $\beta$ and PPAR $\gamma 2$ expression in a prostaglandin-independent fashion. This effect of indomethacin is pertinent to potential deleterious effects of this commonly used anti-inflammatory drug on bone remodeling and tissue healing.

\section{Keywords}

CYCLOOXYGENASE-2; NON-STEROIDAL ANTI-INFLAMMATORY DRUG; PROSTAGLANDIN E2; OSTEOBLAST; FRACTURE HEALING

\begin{abstract}
As the progenitor of bone forming cells, the mesenchymal stem cell (MSC) is critical to bone modeling, remodeling and fracture healing. Importantly, a reciprocal relationship exists between the number of adipocytes and osteoblasts generated from the marrow MSC pool [Akune et al., 2004; Sen et al., 2008]. As such, factors which enhance adipogenic differentiation may negatively impact bone remodeling. Frequently used as analgesics during processes of tissue repair, non-steroidal anti-inflammatory drugs (NSAIDs), and in particular the non-specific cyclooxygenase (COX) inhibitor indomethacin, have been shown to promote adipogenesis and decrease osteogenesis. In vitro culture systems frequently use indomethacin to enhance pre-adipocyte differentiation into mature adipocytes [Williams and Polakis, 1977; Verrando et al., 1981; Knight et al., 1987; Kelly and Gimble, 1998] and it has also been shown to be pro-adipocytic at an earlier stage [Lehmann et al., 1997; Dennis et al., 1999]. The mechanism for the pro-adipogenic effect of indomethacin is controversial. It has
\end{abstract}

(C) 2010 Wiley-Liss, Inc.

*Correspondence to: Dr. Maya Styner, Division of Endocrinology and Metabolism, School of Medicine, University of North Carolina, 5030 Burnett Womack, Chapel Hill, NC 27599-7170. mstyner@med.unc.edu. 
been suggested that inhibition of prostaglandin production might underwrite effects on lineage [Zhang et al., 2002]. Alternatively, indomethacin as well as other NSAIDs may serve as ligands for PPAR $\gamma$, enhancing transcription of critical gene targets important for fat formation [Lehmann et al., 1997].

The rate-limiting step in the conversion of arachidonic acid to prostaglandins is catalyzed by cyclooxygenases, which are inhibited by commonly used NSAIDs. Cyclooxygenase-2 (COX2) and its principal product prostaglandin E2 (PGE2) are thought to play a positive role in bone formation [Cheng et al., 1997; Yoshida et al., 2002; Zhang et al., 2002; Arikawa et al., 2004; Choudhary et al., 2008]. As such, COX2-selective NSAIDs have been associated with delayed fracture healing in rabbits, mice and rats [Goodman et al., 2002; Simon et al., 2002; Naik et al., 2009]; further, they have been shown to decrease the anabolic response to physical loading in rats [Chow and Chambers, 1994; Forwood, 1996]. As well, microCT analysis demonstrates decreased bone density in $\mathrm{COX}^{-/-}$male mice [Robertson et al., 2006] and marrow cultures from these mice suggest that osteoclast formation is impaired [Okada et al., 2000]. Importantly, $\mathrm{COX}^{-/-}$mice display delayed fracture healing and bone marrow stromal cells harvested from these animals form bone nodules at a delayed rate [Zhang et al., 2002]. With respect to bone modeling, administration of PGE2 to animals has been associated with reduced longitudinal growth of bones but an increase in trabecular bone area [Ueno et al., 1985; Suponitzky and Weinreb, 1998]. Taken together, this data suggests that the complex effect of NSAIDs on bone can be only partially explained by the inhibition of cyclooxygenases and reduced prostanoid generation. Developing concepts in the understanding of bone formation indicate that factors which increase adipogenic differentiation of MSCs should have a reciprocal negative effect on osteogenesis [Kang et al., 2007; Sen et al., 2008]. As such, NSAID effects on MSC lineage selection that lead to adipocyte lineage differentiation should be important to processes that require recruitment of alternate lineages.

In this study, we investigate the mechanism by which NSAIDs modulate adipogenesis in C3H10T1/2 pluripotent stem cells as well as marrow-derived mesenchymal stem cells (mdMSCs) [Case et al., 2010]. Our results show that PGE2 has only a minimal effect on early MSC lineage allocation. In contrast, indomethacin promotes adipogenesis in a prostaglandin-independent manner. We provide evidence that indomethacin's adipogenic influence is proximal to PPAR $\gamma$ induction. Our work suggests that indomethacin may have potential deleterious effects during times of bone and tissue healing when lineage selection is critical.

\section{MATERIALS AND METHODS REAGENTS}

Lipofectamine 2000, reverse transcriptase, siRNA and Taq polymerase were obtained from Invitrogen (Carlsbad, CA). Arachidonic acid, PGE2, and 15-deoxy-PGJ2 were from SigmaAldrich (St. Louis, MO). Rosiglitazone was obtained from Cayman Chemicals (Ann Arbor, MI). Celecoxib was obtained from LKT Labs (St. Paul, MN). Luciferase assay reagents were from Promega (Madison, WI).

\section{CELL CULTURE}

C3H10T1/2 pluripotent stem cells were maintained in growth medium (a-MEM, 10\% FBS, $100 \mu \mathrm{g} / \mathrm{ml}$ penicillin/streptomycin). Cells were plated in six-well plates at a density of 1 $\mathrm{i} \times 10^{5}$ except as otherwise noted one day prior to initiation of experiments. Adipogenic medium including $0.1 \mu \mathrm{M}$ dexamethasone and $5 \mu \mathrm{g} / \mathrm{ml}$ insulin was added on day zero. For the 7-day experiments, adipogenic medium was replaced on day 4. 
Key experiments were replicated in a marrow derived mesenchymal stem cell line generated from C56/BL6 wild-type mice using the procedure of Peister et al. [2004] and Case et al. [2010]. These cells readily undergo differentiation into osteogenic, adipogenic or alternative lineages using standard differentiation media [Case et al., 2010]. Cells were plated under similar adipogenic conditions as detailed above. We have termed these cells "marrow derived MSC" (mdMSC) in the text. Both C3H10T1/2 as well as mdMSC are referred to as MSCs throughout the text; figure legends specify the cell type used.

\section{RNA INTERFERENCE}

Cells were transfected with siRNA $(50 \mathrm{~nm})$ in serum-free OptiMEM for 4-6 h using lipofectamine 2000 reagent per the manufacturer protocol. After transfection, cells were placed in adipogenic media. Three days after transfection, RNA and protein analyses were performed.

\section{PROTEIN ANALYSIS}

Whole cell lysates were prepared with lysis buffer $(150 \mathrm{mM} \mathrm{NaCl}, 50 \mathrm{mM}$ Tris $\mathrm{HCl}, 1 \mathrm{mM}$ EGTA, $0.24 \%$ sodium deoxycholate, $1 \%$ IGEPAL, $\mathrm{pH} 7.5$ ) containing $25 \mathrm{mM} \mathrm{NaF}$ and $2 \mathrm{mM}$ $\mathrm{Na} 3 \mathrm{VO} 4$, aprotinin, leupeptin, pepstatin and PMSF. Whole lysate proteins $(15-20 \mu \mathrm{g})$ were loaded onto a $8.5-12 \%$ polyacrylamide gel for chromatography and transferred to PVDF membrane. After blocking, primary antibody was applied overnight at $4^{\circ} \mathrm{C}$ including antibodies against active $\beta$-catenin (clone 8E7, Upstate, Temecula, CA), total $\beta$-catenin (BD, Bedford, MA), PPAR $\gamma$, adiponectin, COX2, $\beta$-tubulin (Santa Cruz, CA), aP2 (ProSci, Inc., Poway, CA), and C/EBP $\beta$ (Cell Signaling, Danvers, MA). Secondary antibody conjugated with horseradish peroxidase was detected with ECL plus chemiluminescence kit (Amersham Biosciences, Piscataway, NJ). Densitometry was determined using NIH ImageJ, $1.37 \mathrm{v}$.

\section{REAL-TIME RT-PCR}

Total RNA was isolated with the RNeasy mini kit (Qiagen, Valencia CA) and treated with DNase I. Reverse transcription of $1 \mathrm{mg}$ of RNA was performed prior to real-time PCR (BioRad iCycler, Hercules, CA). Amplification reactions contained primers $(0.5 \mu \mathrm{M})$, dNTPs (0.2mM each), 0.03 U Taq polymerase and SYBR-green (Molecular Probes, Eugene, $\mathrm{OR}$ ) at 1:150,000. Aliquots of cDNA were diluted 5- to 5,000-fold to generate relative standard curves to which sample cDNA was compared. PPAR $\gamma$, adiponectin, COX2, and $18 \mathrm{~S}$ primers were as in Case et al. [2008] and Sen et al. [2008]. For C/EBP $\beta$ forward and reverse primers were $5^{\prime}$-CAAGCTGAG-CGACGAGTACA- $3^{\prime}$ and $5^{\prime}$ AGCTGCTCCACCTTCTTCTG- $3^{\prime}$, respectively. Standards and samples were run in triplicate. PCR products were normalized to $18 \mathrm{~S}$ amplicons in the RT sample, and standardized on a dilution curve from RT sample.

\section{PLASMIDS, DNA TRANSFECTION, AND LUCIFERASE ASSAY}

The FLAG-PPAR $\gamma 2$ plasmid was a gift from Dr. Monte Willis (UNC). The pCMV-RXRa plasmid was a gift from Dr. Mark Nanes (Emory University) [Farmer et al., 2000]. Cells (1 $\times 10^{5}$ ) were seeded in 12-well plates in duplicate. On day zero, cells were transfected with FLAG-PPAR $\gamma 2(0.2 \mu \mathrm{g})$ and pCMV-RXRa $(0.2 \mu \mathrm{g})$ versus pCDNA3.1 expression vector $(0.4 \mu \mathrm{g})$ as well as with the PPRE-luciferase construct $\mathrm{pCPE}-2.6 \mathrm{~kb}(29)(0.35 \mu \mathrm{g})$ versus salmon sperm DNA $(0.35 \mu \mathrm{g})$. $\beta$-Galactosidase $(0.05 \mu \mathrm{g})$ was used to control for transfection efficiency in all wells. Lipofectamine 2000 reagent was used according to the manufacturer protocol $(2 \mu \mathrm{l} / \mathrm{well})$. Four to six hours after transfection, the media was changed to a-MEM. Indomethacin, rosiglitazone, 15-deoxy-PGJ2 or vehicle was added $24 \mathrm{~h}$ after transfection. Cell lysates were collected $48 \mathrm{~h}$ after transfection using the reporter lysis buffer (Promega). 
Luciferase assays were performed with the Luciferase Assay system (Promega) and GalactoStar ${ }^{\text {TM }}$ (Applied Biosystems, Bedford, MA). Ninety six-well plates were read via the GloMax Luminometer (Promega).

\section{PGE2 ELISA MEASUREMENT}

Cells $\left(1 \times 10^{5}\right)$ were seeded in 24-well plates in duplicate. One day later, cells were treated with arachidonic acid, indomethacin and celecoxib at indicated concentrations. Twenty-four hours later, cell culture media was analyzed PGE2 and ELISA kit from Assay Designs (Ann Arbor, MI).

\section{STATISTICAL ANALYSIS}

Results are expressed as mean \pm SEM. Statistical significance was evaluated by one-way ANOVA with a Tukey's post hoc test, a two-way ANOVA with a Bonferroni posttest or $t$ test (GraphPad Prism). All experiments were replicated at least once to assure reproducibility. Statistical significance is indicated on graphs as follows: $* P<0.05, * * P<$ $0.01, * * * P<0.001$.

\section{RESULTS}

\section{INDOMETHACIN IS A POTENT STIMULATOR OF ADIPOGENESIS IN MSCS}

MSCs were cultured in adipogenic media containing insulin and dexamethasone with additions as noted of rosiglitazone, a known PPAR $\gamma$ ligand, indomethacin, or the specific COX2 inhibitor, celecoxib. The cells were stained for oil red $\mathrm{O}$ stain to show presence of lipid droplets indicating the formation of adipocytes. After 3 days in adipogenicmedia, MSCs contained no lipid droplets (Fig. 1A). The addition of indomethacin $(10 \mu \mathrm{M})$ induced appearance of lipid droplets at a level similar to that of an equimolar dose of rosiglitazone. The more commonly used adipogenic dose of indomethacin, $50 \mu \mathrm{M}$ [Sen et al., 2008], or a higher dose of rosiglitazone $(20 \mu \mathrm{M})$ were able to further increase the number of lipid containing cells by oil red $\mathrm{O}$ (data not shown). In contrast to indomethacin, celecoxib at doses from 1 to $50 \mu \mathrm{M}$ failed to induce adipogenesis. Celecoxib doses equal to or greater than $20 \mu \mathrm{M}$ were toxic to the MSCs with excessive cell death consistent with other reports for other cells [Chuang et al., 2008].

Proteins consistent with adipogenic differentiation were analyzed. As shown in Figure 1B, aP2 protein was equally upregulated by indomethacin and rosiglitazone at 50 and $10 \mu \mathrm{M}$ respectively, suggesting similar induction of adipogenesis. In contrast, PPAR $\gamma 2$ was more significantly increased by indomethacin as compared with rosiglitazone by Western blot (Fig. 1B). Densitometry of bands from at least two separate experiments show that while doses of indomethacin, that had an equivalent effect to rosiglitazone to increase aP2, caused a significantly greater increase in PPAR $\gamma 2$. Celecoxib failed to stimulate either PPAR $\gamma 2$ or aP2 (1B).

We confirmed that indomethacin upregulates PPAR $\gamma 2$ and aP2 in marrow derived MSC. Shown in Figure 1C, mdMSC treated with indomethacin $50 \mu \mathrm{M}$ express both PPAR $\gamma 2$ or aP2 protein, as well as stain for lipid (data not shown). Celecoxib did not cause adipogenesis in mdMSCs (1C).

\section{INDOMETHACIN ACCELERATES ADIPOGENESIS AND DECREASES $\beta$-CATENIN}

Indomethacin induction of PPAR $\gamma 2$ mRNA was measurable by day 2 (Fig. 2A) resulting in peak PPAR $\gamma$ protein at day 4 followed by a decline by day 7 (Fig. 2B). Adiponectin and aP2 proteins were also measurable by day 2, peaking at day 4 (Fig. 2B). The decrease in total and active $\beta$-catenin that typically accompanies adipogenesis [Moldes et al., 2003; Sen et al., 
2008, 2009] was accelerated in the presence of indomethacin (Fig. 2B). Similarly, COX2 expression was significantly reduced early in the course of adipogenesis as shown by RTPCR (Fig. 2A) and Western (Fig. 2B).

\section{INDOMETHACIN'S ADIPOGENIC EFFECT IS INDEPENDENT OF COX2 AND PGE2}

Indomethacin effectively induced adipogenesis at a dose of $5 \mu \mathrm{M}$, increasing both adiponectin and aP2 protein at 2 days; celecoxib $(5 \mu \mathrm{M})$ failed to replicate this effect (Fig. $3 \mathrm{~A}$, upper panel). Furthermore, indomethacin's effect was dose dependent as evidenced by increasing levels of aP2 protein expression with increases of the drug to $50 \mu \mathrm{M}$ (Fig. 3A, lower panel). Celecoxib increased aP2 above control levels at day 2 but this effect was not dose dependent, and was not associated with increased adiponectin. This effect of celecoxib on aP2 at the early time point was inconsistent and did not develop in the next several days. This allowed us to conclude that this agent, which potently suppressed PGE2 production, did not induce adipogenesis.

The effect of indomethacin to enhance adipogenesis has been attributed to the inhibition of prostaglandins including the major product of the COX2 enzyme, PGE2. To confirm that indomethacin and celecoxib successfully inhibited $\mathrm{COX} 2$, arachidonic acid was used to stimulate PGE2 production by providing substrate for COX. PGE2 ELISA analysis of media collected $24 \mathrm{~h}$ after treatments revealed robust PGE2 production in the presence of arachidonic acid (Fig. 3B). Both indomethacin and celecoxib effectively prevented PGE2 production.

Furthermore, PGE2 addition did not inhibit adipogenesis. MSCs were cultured in adipogenic media in the presence and absence of indomethacin along with PGE2 $(5 \mu \mathrm{M})$ which was readded on day 2. Measured on day 4, indomethacin induction of expression of adiponectin and PPAR $\gamma$ was unaffected by PGE2 addition (Fig. 4A). This was confirmed by Western analysis (Fig. 4B).

To rule out a role for other COX2 generated prostaglandins, siRNA to COX2 was employed. Seventy-two hours after transfection, siRNA knockdown of COX2 not only did not enhance adipogenesis but appeared to have inhibitory effects on PPAR $\gamma 2$ and adiponectin expression (Fig. 4C). Western blot data for adiponectin, aP2 and PPAR $\gamma 2$ supported this expression data (Fig. 4D). COX2 knockdown was effective in cultures in growth media (data not shown), but knockdown could not be demonstrated by Western blot as COX2 protein decreased sharply during adipogenesis in all cultures.

\section{INDOMETHACIN DOES NOT FUNCTION AS A PPARY LIGAND IN MSC}

Indomethacin has previously been shown to ligate PPAR $\gamma$ in C3H10T1/2 cells [Lehmann et al., 1997]; thus we considered whether this could also serve as the mechanism by which indomethacin affected aP2 and adiponectin expression. To control for indomethacin induced changes in PPAR $\gamma$ level (see Fig. 1), both PPAR $\gamma 2$-FLAG and RXRa were transiently overexpressed in MSCs prior to initiation of experiment. PPAR $\gamma 2$ expression was confirmed by Western blot using antibodies to FLAG and PPAR $\gamma 224 \mathrm{~h}$ after transfection with the FLAG-PPAR $\gamma 2$ plasmid (Fig. 5A). PPAR $\gamma$ agonists rosiglitazone and 15d-PGJ2 significantly induced PPRE (1.7- and 1.3-fold that of control respectively, $P<0.01$, Fig. $5 B$ ). In contrast, indomethacin increased PPRE-driven-luciferase (PPRE-LUC) activity to 1.1-fold that of control, an effect which was not significant. Additionally, indomethacin at doses from 10 to $200 \mu \mathrm{M}$ failed to activate PPRE-LUC (data not shown). Thus, at levels which potently induced adipogenesis, indomethacin did not significantly enhance PPAR $\gamma$ activated transcription. 


\section{INDOMETHACIN INCREASES LEVELS OF C/EBP $\beta$ IN A DOSE-DEPENDENT ASHION}

Given that indomethacin increases PPAR $\gamma 2$ expression and that $C / E B P \beta$ functions upstream of PPAR $\gamma 2$, we investigated C/EBP $\beta$ as a possible target of indomethacin. C/EBP $\beta$ expression increased in the presence of indomethacin in a time course that predicted the rise in PPAR $\gamma 2$ and APN expression. C/EBP $\beta$ mRNA rose by day 2 and remained elevated at day 3 (Fig. 6A, left panel) in the C3H10T1/2 stem cells. In mdMSCs C/EBP $\beta$ was similarly induced by indomethacin at day 3 (Fig. 6A, right panel): expression of C/EBP $\beta$ was increased fourfold by day 1 in adipogenic media without indomethacin and by day 3 , indomethacin maximally upregulated the expression of C/EBP $\beta$ to eightfold in three separate experiments. Expression was confirmed by Western blot analysis showing that upregulation of $\mathrm{C} / \mathrm{EBP} \beta$ protein occurred in a dose-dependent fashion (Fig. 6B). By day 3, indomethacin's effect on $\mathrm{C} / \mathrm{EBP} \beta$ protein expression was maximal.

\section{DISCUSSION}

Control of mesenchymal stem cell lineage selection is central to regeneration and repair of tissues. In particular, the allocation of MSC into the adipogenic lineage at the expense of the osteogenic output appears to contribute to bone pathology: increased marrow fat in place of trabecular bone is associated with aging [Yeung et al., 2005], the nutritional defect in anorexia nervosa [Abella et al., 2002] and with thiozolidinedione induced bone fragility [Kahn et al., 2006; Grey, 2008]. The widely available non-steroidal anti-inflammatory class of drugs (NSAIDs), have been shown to affect bone healing [Simon et al., 2002; Zhang et al., 2002], an effect which has been presumed to be due to a primary role for the COX2 product, PGE2, on both osteogenesis and chondrogenesis [Zhang et al., 2002]. Human studies provide inconclusive data in this regard but suggest NSAID may negatively affect fracture healing [Adolphson et al., 1993; Burd et al., 2003]. Here we have shown that the commonly used NSAID, indomethacin, has a unique and profound prostaglandinindependent effect to promote adipogenesis in C3H10T1/2 pluripotent stem cells as well as marrow-derived MSCs. As such, our work has implications for the use of this drug during tissue repair, as it may limit the ability for MSCs to enter cell lineages critical to healing of tissues. Prior work indicates that the C3H10T1/2 cell line is a faithful model of MSC stem cell commitment in vitro [Tang et al., 2004; Bowers et al., 2006; Huang et al., 2009]. Additionally, when implanted into athymic mice, C3H10T1/2 stem cells treated with adipogenic stimuli differentiate into tissue that is indistinguishable from endogenous adipose tissue in vivo [Tang et al., 2004]. In order to confirm physiologic relevance of our findings in the C3H10T1/2 stem cells, key experiments were reproduced using murine marrowderived MSCs as well; these experiments confirmed indomethacin's effects to cause adipogenesis.

The pro-adipogenic properties of indomethacin were recognized as early as the 1970s [Williams and Polakis, 1977; Verrando et al., 1981; Knight et al., 1987] and the drug became an established component of an adipogenic cocktail utilized in laboratories. The mechanism of adipogenesis had been thought to involve either inhibition of PGE2 or by enhancing the action of the central adipocyte transcription factor PPAR $\gamma$. Our data indicates that indomethacin's unique role in promoting early adipogenesis is, in fact, separate from its effects on COX2 or prostaglandins generated from COX2. Further, rather than enhancing PPAR $\gamma$-activated transcriptional activity, we found that indomethacin increased PPAR $\gamma 2$ protein to levels far above those seen after treatment with rosiglitazone, an effect certainly central to the adipogenic effect of the NSAID. It is also possible that indomethacin affects PPAR $\gamma 2$ through post-transcriptional mechanisms.

Celecoxib, a potent inhibitor of COX2 and prostaglandin production, had little effect on MSC lineage allocation. Knockdown of COX2 also failed to replicate the strong adipogenic 
effect of indomethacin, suggesting that COX2 products were not involved. PGE2, the principal product of $\mathrm{COX} 2$, has been considered to function as anabolic agent that both promotes osteoblastogenesis and decreases adipogenesis [Zhang et al., 2002]. This view should be modified in light of the fact that $\mathrm{COX} 2^{-/-}$mice have no fat phenotype and a minimal bone phenotype is found in males only [Robertson et al., 2006]. In vivo administration of PGE2 has, further, not been consistently anabolic [Ueno et al., 1985; Suponitzky and Weinreb, 1998] and in our experiments, PGE2 failed to prevent early adipogenesis. Interestingly, Xie et al. [2009] recently demonstrated that COX2 and PGE2 contribute to angiogenesis in the setting of fracture healing, invoking a new level of prostaglandin regulation of processes central to bone remodeling. Thus, while COX2 and PGE2 may have roles in the pathologic setting of fracture healing, a clear role for prostanoid signaling during MSC differentiation has not emerged [Zhang et al., 2002; Xie et al., 2009].

A growing body of literature supports non-cyclooxygenase mediated mechanisms for NSAIDs [Tegeder et al., 2001]. These drugs can have differential effects on transcription factors, MAP kinases, and cell cycle regulators [Tegeder et al., 2001]. Indomethacin induction of gastric ulceration was originally ascribed to inhibition of COX1 and prostaglandin production, however prostaglandin failed to reverse effects of indomethacin in gastric cell culture [Langenbach et al., 1995; Kokoska et al., 1998]. Additionally, antitumor effects of celecoxib in colorectal cancer cells appear to be mediated via COX-2 independent mechanisms [Grosch et al., 2001]. Indomethacin's COX-independent promotion of adipogenesis can now be added to this list.

Although indomethacin has been shown to bind PPAR 22 [Lehmann et al., 1997], doses that strongly induce adipogenesis failed to activate a PPRE-driven reporter construct. Our results contrast with those of Lehmann et al. [1997]: it is possible that rising PPAR $\gamma 2$ levels enhanced expression of the aP2 promoter used in those experiments. Our experiments controlled for indomethacin's strong induction of PPAR $\gamma 2$ by forced expression of both PPAR $\gamma 2$ and RXRa in the target cells. An interaction between indomethacin and the ligand binding domain (LBD) of PPAR $\gamma 2$ has also been suggested [Lehmann et al., 1997]; that other NSAIDs at very high doses have been shown to interact with the PPAR $\gamma$ LBD yet none induce adipogenesis suggests that induction of adipogenesis by indomethacin is not via this association. Furthermore, the profound upregulation of PPAR $\gamma 2$ expression induced by indomethacin indicates that crucial events take place upstream of PPAR $\gamma 2$.

$\mathrm{C} / \mathrm{EBP} \beta$ serves as transcription factor required early during adipogenesis [Park et al., 2004]. A C/EBP $\beta$ dominant-negative mutation that fails to enter the nucleus of 3T3-L1 cells blocked mitotic clonal expansion of pre-adipocytes [Zhang et al., 2004]. The induction of C/ EBP $\beta$ due to indomethacin thus likely precedes the downstream expression of PPAR $\gamma 2$. Indomethacin has been found to induce Nur77 [Kang et al., 2000], a member of the of the steroidthyroid hormone nuclear receptor family. Given that Nur 77 has been linked to early adipogenic conversion [Fumoto et al., 2007] it is possible that indomethacin via effects on Nur77 DNA-binding might result in increased transcription of C/EBP $\beta$. Interestingly, new evidence has emerged linking C/EBP $\beta$ to endoplasmic reticulum (ER) stress [Matsuda et al., 2010], and contributors to the ER stress response are directly dependent on C/EBP $\beta$ and have been shown to be required for adipogenesis [Sha et al., 2009]. As indomethacin has been shown to increase markers of ER stress like BiP (Grp78) and CHOP [Tsutsumi et al., 2004], it is possible that indomethacin upregulation of C/EBP $\beta$ is interlinked with ER stress.

In summary, our results indicate that indomethacin strongly promotes adipogenesis through a prostaglandin independent mechanism that increases both C/EBP $\beta$ and PPAR $\gamma 2$. Understanding the effect of NSAIDs, and in particular indomethacin, on lineage allocation 
of MSC is important not only because NSAIDs are commonly used drugs, but also because they shed light on mechanisms involved in early adipogenesis.

\section{Acknowledgments}

Grant sponsor: NIH; Grant numbers: DK007129, AR042360, AR52014.

\section{References}

Abella E, Feliu E, Granada I, Milla F, Oriol A, Ribera JM, Sanchez-Planell L, Berga LI, Reverter JC, Rozman C. Bone marrow changes in anorexia nervosa are correlated with the amount of weight loss and not with other clinical findings. Am J Clin Pathol. 2002; 118:582-588. [PubMed: 12375646]

Adolphson P, Abbaszadegan H, Jonsson U, Dalen N, Sjoberg HE, Kalen S. No effects of piroxicam on osteopenia and recovery after Colles' fracture. A randomized, double-blind, placebo-controlled, prospective trial. Arch Orthop Trauma Surg. 1993; 112:127-130. [PubMed: 8323840]

Akune T, Ohba S, Kamekura S, Yamaguchi M, Chung UI, Kubota N, Terauchi Y, Harada Y, Azuma Y, Nakamura K, Kadowaki T, Kawaguchi H. PPARgamma insufficiency enhances osteogenesis through osteoblast formation from bone marrow progenitors. J Clin Invest. 2004; 113:846-855. [PubMed: 15067317]

Arikawa T, Omura K, Morita I. Regulation of bone morphogenetic protein-2 expression by endogenous prostaglandin E2 in human mesenchymal stem cells. J Cell Physiol. 2004; 200:400406. [PubMed: 15254968]

Bowers RR, Kim JW, Otto TC, Lane MD. Stable stem cell commitment to the adipocyte lineage by inhibition of DNA methylation: Role of the BMP-4 gene. Proc Natl Acad Sci USA. 2006; 103:13022-13027. [PubMed: 16916928]

Burd TA, Hughes MS, Anglen JO. Heterotopic ossification prophylaxis with indomethacin increases the risk of long-bone nonunion. J Bone Joint Surg Br. 2003; 85:700-705. [PubMed: 12892193]

Case N, Ma M, Sen B, Xie Z, Gross TS, Rubin J. Beta-catenin levels influence rapid mechanical responses in osteoblasts. J Biol Chem. 2008; 283:29196-29205. [PubMed: 18723514]

Case N, Xie Z, Sen B, Styner M, Zou M, O’Conor C, Horowitz M, Rubin J. Mechanical activation of beta-catenin regulates phenotype in adult murine marrow-derived mesenchymal stem cells. J Orthop Res. 2010 Available at: http://onlinelibrary.wiley.com/doi/10.1002/jor.21156/abstract.

Cheng MZ, Zaman G, Rawlinson SC, Pitsillides AA, Suswillo RF, Lanyon LE. Enhancement by sex hormones of the osteoregulatory effects of mechanical loading and prostaglandins in explants of rat ulnae. J Bone Miner Res. 1997; 12:1424-1430. [PubMed: 9286758]

Choudhary S, Alander C, Zhan P, Gao Q, Pilbeam C, Raisz L. Effect of deletion of the prostaglandin $\mathrm{EP} 2$ receptor on the anabolic response to prostaglandin E2 and a selective EP2 receptor agonist. Prostaglandins Other Lipid Mediat. 2008; 86:35-40. [PubMed: 18406186]

Chow JW, Chambers TJ. Indomethacin has distinct early and late actions on bone formation induced by mechanical stimulation. Am J Physiol. 1994; 267:E287-E292. [PubMed: 8074209]

Chuang HC, Kardosh A, Gaffney KJ, Petasis NA, Schonthal AH. COX-2 inhibition is neither necessary nor sufficient for celecoxib to suppress tumor cell proliferation and focus formation in vitro. Mol Cancer. 2008; 7:38. [PubMed: 18485224]

Dennis JE, Merriam A, Awadallah A, Yoo JU, Johnstone B, Caplan AI. A quadripotential mesenchymal progenitor cell isolated from the marrow of an adult mouse. J Bone Miner Res. 1999; 14:700-709. [PubMed: 10320518]

Farmer PK, He X, Schmitz ML, Rubin J, Nanes MS. Inhibitory effect of NF-kappaB on 1,25dihydroxyvitamin D(3) and retinoid X receptor function. Am J Physiol Endocrinol Metab. 2000; 279:E213-E220. [PubMed: 10893342]

Forwood MR. Inducible cyclo-oxygenase (COX-2) mediates the induction of bone formation by mechanical loading in vivo. J Bone Miner Res. 1996; 11:1688-1693. [PubMed: 8915776]

Fumoto T, Yamaguchi T, Hirose F, Osumi T. Orphan nuclear receptor Nur77 accelerates the initial phase of adipocyte differentiation in 3T3-L1 cells by promoting mitotic clonal expansion. $\mathrm{J}$ Biochem. 2007; 141:181-192. [PubMed: 17167038] 
Goodman S, Ma T, Trindade M, Ikenoue T, Matsuura I, Wong N, Fox N, Genovese M, Regula D, Smith RL. COX-2 selective NSAID decreases bone ingrowth in vivo. J Orthop Res. 2002; 20:1164-1169. [PubMed: 12472224]

Grey A. Skeletal consequences of thiazolidinedione therapy. Osteoporos Int. 2008; 19:129-137. [PubMed: 17901911]

Grosch S, Tegeder I, Niederberger E, Brautigam L, Geisslinger G. COX-2 independent induction of cell cycle arrest and apoptosis in colon cancer cells by the selective COX-2 inhibitor celecoxib. FASEB J. 2001; 15:2742-2744. [PubMed: 11606477]

Huang H, Song TJ, Li X, Hu L, He Q, Liu M, Lane MD, Tang QQ. BMP signaling pathway is required for commitment of C3H10T1/2 pluripotent stem cells to the adipocyte lineage. Proc Natl Acad Sci USA. 2009; 106:12670-12675. [PubMed: 19620713]

Kahn SE, Haffner SM, Heise MA, Herman WH, Holman RR, Jones NP, Kravitz BG, Lachin JM, O’Neill MC, Zinman B, Viberti G. Glycemic durability of rosiglitazone, metformin, or glyburide monotherapy. N Engl J Med. 2006; 355:2427-2443. [PubMed: 17145742]

Kang HJ, Song MJ, Choung SY, Kim SJ, Le MO. Transcriptional induction of Nur77 by indomethacin that results in apoptosis of colon cancer cells. Biol Pharm Bull. 2000; 23:815-819. [PubMed: 10919358]

Kang S, Bennett CN, Gerin I, Rapp LA, Hankenson KD, Macdougald OA. Wnt signaling stimulates osteoblastogenesis of mesenchymal precursors by suppressing CCAAT/enhancer-binding protein alpha and peroxisome proliferator- activated receptor gamma. J Biol Chem. 2007; 282:1451514524. [PubMed: 17351296]

Kelly KA, Gimble JM. 1,25-Dihydroxy vitamin D3 inhibits adipocyte differentiation and gene expression in murine bone marrow stromal cell clones and primary cultures. Endocrinology. 1998; 139:2622-2628. [PubMed: 9564879]

Knight DM, Chapman AB, Navre M, Drinkwater L, Bruno JJ, Ringold GM. Requirements for triggering of adipocyte differentiation by glucocorticoids and indomethacin. Mol Endocrinol. 1987; 1:36-43. [PubMed: 3454870]

Kokoska ER, Smith GS, Deshpande Y, Wolff AB, Miller TA. Indomethacin increases susceptibility to injury in human gastric cells independent of PG synthesis inhibition. Am J Physiol. 1998; 275:G620-G628. [PubMed: 9756489]

Langenbach R, Morham SG, Tiano HF, Loftin CD, Ghanayem BI, Chulada PC, Mahler JF, Lee CA, Goulding EH, Kluckman KD, Kim HS, Smithies O. Prostaglandin synthase 1 gene disruption in mice reduces arachidonic acidinduced inflammation and indomethacin-induced gastric ulceration. Cell. 1995; 83:483-492. [PubMed: 8521478]

Lehmann JM, Lenhard JM, Oliver BB, Ringold GM, Kliewer SA. Peroxisome proliferator-activated receptors alpha and gamma are activated by indomethacin and other non-steroidal antiinflammatory drugs. J Biol Chem. 1997; 272:3406-3410. [PubMed: 9013583]

Matsuda T, Kido Y, Asahara S, Kaisho T, Tanaka T, Hashimoto N, Shigeyama Y, Takeda A, Inoue T, Shibutani Y, Koyanagi M, Hosooka T, Matsumoto M, Inoue H, Uchida T, Koike M, Uchiyama Y, Akira S, Kasuga M. Ablation of C/EBPbeta alleviates ER stress and pancreatic beta cell failure through the GRP78 chaperone in mice. J Clin Invest. 2010; 120:115-126. [PubMed: 19955657]

Moldes M, Zuo Y, Morrison RF, Silva D, Park BH, Liu J, Farmer SR. Peroxisome-proliferatoractivated receptor gamma suppresses $\mathrm{Wnt} /$ betacatenin signalling during adipogenesis. Biochem J. 2003; 376:607-613. [PubMed: 12954078]

Naik AA, Xie C, Zuscik MJ, Kingsley P, Schwarz EM, Awad H, Guldberg R, Drissi H, Puzas JE, Boyce B, Zhang X, O'Keefe RJ. Reduced COX-2 expression in aged mice is associated with impaired fracture healing. J Bone Miner Res. 2009; 24:251-264. [PubMed: 18847332]

Okada Y, Lorenzo JA, Freeman AM, Tomita M, Morham SG, Raisz LG, Pilbeam CC. Prostaglandin $\mathrm{G} / \mathrm{H}$ synthase-2 is required for maximal formation of osteoclast-like cells in culture. J Clin Invest. 2000; 105:823-832. [PubMed: 10727451]

Park BH, Qiang L, Farmer SR. Phosphorylation of C/EBPbeta at a consensus extracellular signalregulated kinase/glycogen synthase kinase 3 site is required for the induction of adiponectin gene expression during the differentiation of mouse fibroblasts into adipocytes. Mol Cell Biol. 2004; 24:8671-8680. [PubMed: 15367685] 
Peister A, Mellad JA, Larson BL, Hall BM, Gibson LF, Prockop DJ. Adult stem cells from bone marrow (MSCs) isolated from different strains of inbred mice vary in surface epitopes, rates of proliferation, and differentiation potential. Blood. 2004; 103:1662-1668. [PubMed: 14592819]

Robertson G, Xie C, Chen D, Awad H, Schwarz EM, O'Keefe RJ, Guldberg RE, Zhang X. Alteration of femoral bone morphology and density in COX-2 ${ }^{-/}$mice. Bone. 2006; 39:767-772. [PubMed: 16731065]

Sen B, Xie Z, Case N, Ma M, Rubin C, Rubin J. Mechanical strain inhibits adipogenesis in mesenchymal stem cells by stimulating a durable beta-catenin signal. Endocrinology. 2008; 149:6065-6075. [PubMed: 18687779]

Sen B, Styner M, Xie Z, Case N, Rubin CT, Rubin J. Mechanical loading regulates NFATc1 and betacatenin signaling through a GSK3beta control node. J Biol Chem. 2009; 284:34607-34617. [PubMed: 19840939]

Sha H, He Y, Chen H, Wang C, Zenno A, Shi H, Yang X, Zhang X, Qi L. The IRE1alpha-XBP1 pathway of the unfolded protein response is required for adipogenesis. Cell Metab. 2009; 9:556564. [PubMed: 19490910]

Simon AM, Manigrasso MB, O'Connor JP. Cyclo-oxygenase 2 function is essential for bone fracture healing. J Bone Miner Res. 2002; 17:963-976. [PubMed: 12054171]

Suponitzky I, Weinreb M. Differential effects of systemic prostaglandin E2 on bone mass in rat long bones and calvariae. J Endocrinol. 1998; 156:51-57. [PubMed: 9496233]

Tang QQ, Otto TC, Lane MD. Commitment of C3H10T1/2 pluripotent stem cells to the adipocyte lineage. Proc Natl Acad Sci USA. 2004; 101:9607-9611. [PubMed: 15210946]

Tegeder I, Pfeilschifter J, Geisslinger G. Cyclooxygenase-independent actions of cyclooxygenase inhibitors. FASEB J. 2001; 15:2057-2072. [PubMed: 11641233]

Tsutsumi S, Gotoh T, Tomisato W, Mima S, Hoshino T, Hwang HJ, Takenaka H, Tsuchiya T, Mori M, Mizushima T. Endoplasmic reticulum stress response is involved in nonsteroidal antiinflammatory drug-induced apoptosis. Cell Death Differ. 2004; 11:1009-1016. [PubMed: 15131590]

Ueno K, Haba T, Woodbury D, Price P, Anderson R, Jee WS. The effects of prostaglandin E2 in rapidly growing rats: Depressed longitudinal and radial growth and increased metaphyseal hard tissue mass. Bone. 1985; 6:79-86. [PubMed: 3860213]

Verrando P, Negrel R, Grimaldi P, Murphy M, Ailhaud G. Differentiation of ob 17 preadipocytes to adipocytes. Triggering effects of clofenapate and indomethacin. Biochim Biophys Acta. 1981; 663:255-265. [PubMed: 7011414]

Williams IH, Polakis SE. Differentiation of 3T3-L1 fibroblasts to adipocytes. The effect of indomethacin, prostaglandin E1 and cyclic AMP on the process of differentiation. Biochem Biophys Res Commun. 1977; 77:175-186. [PubMed: 196597]

Xie C, Liang B, Xue M, Lin AS, Loiselle A, Schwarz EM, Guldberg RE, O'Keefe RJ, Zhang X. Rescue of impaired fracture healing in COX-2 $2^{-/-}$mice via activation of prostaglandin $\mathrm{E} 2$ receptor subtype 4. Am J Pathol. 2009; 175:772-785. [PubMed: 19628768]

Yeung DK, Griffith JF, Antonio GE, Lee FK, Woo J, Leung PC. Osteoporosis is associated with increased marrow fat content and decreased marrow fat unsaturation: A proton MR spectroscopy study. J Magn Reson Imaging. 2005; 22:279-285. [PubMed: 16028245]

Yoshida K, Oida H, Kobayashi T, Maruyama T, Tanaka M, Katayama T, Yamaguchi K, Segi E, Tsuboyama T, Matsushita M, Ito K, Ito Y, Sugimoto Y, Ushikubi F, Ohuchida S, Kondo K, Nakamura T, Narumiya S. Stimulation of bone formation and prevention of bone loss by prostaglandin E EP4 receptor activation. Proc Natl Acad Sci USA. 2002; 99:4580-4585. [PubMed: 11917107]

Zhang X, Schwarz EM, Young DA, Puzas JE, Rosier RN, O'Keefe RJ. Cyclooxygenase-2 regulates mesenchymal cell differentiation into the osteoblast lineage and is critically involved in bone repair. J Clin Invest. 2002; 109:1405-1415. [PubMed: 12045254]

Zhang JW, Tang QQ, Vinson C, Lane MD. Dominant-negative C/EBP disrupts mitotic clonal expansion and differentiation of 3T3-L1 preadipocytes. Proc Natl Acad Sci USA. 2004; 101:4347. [PubMed: 14688407] 


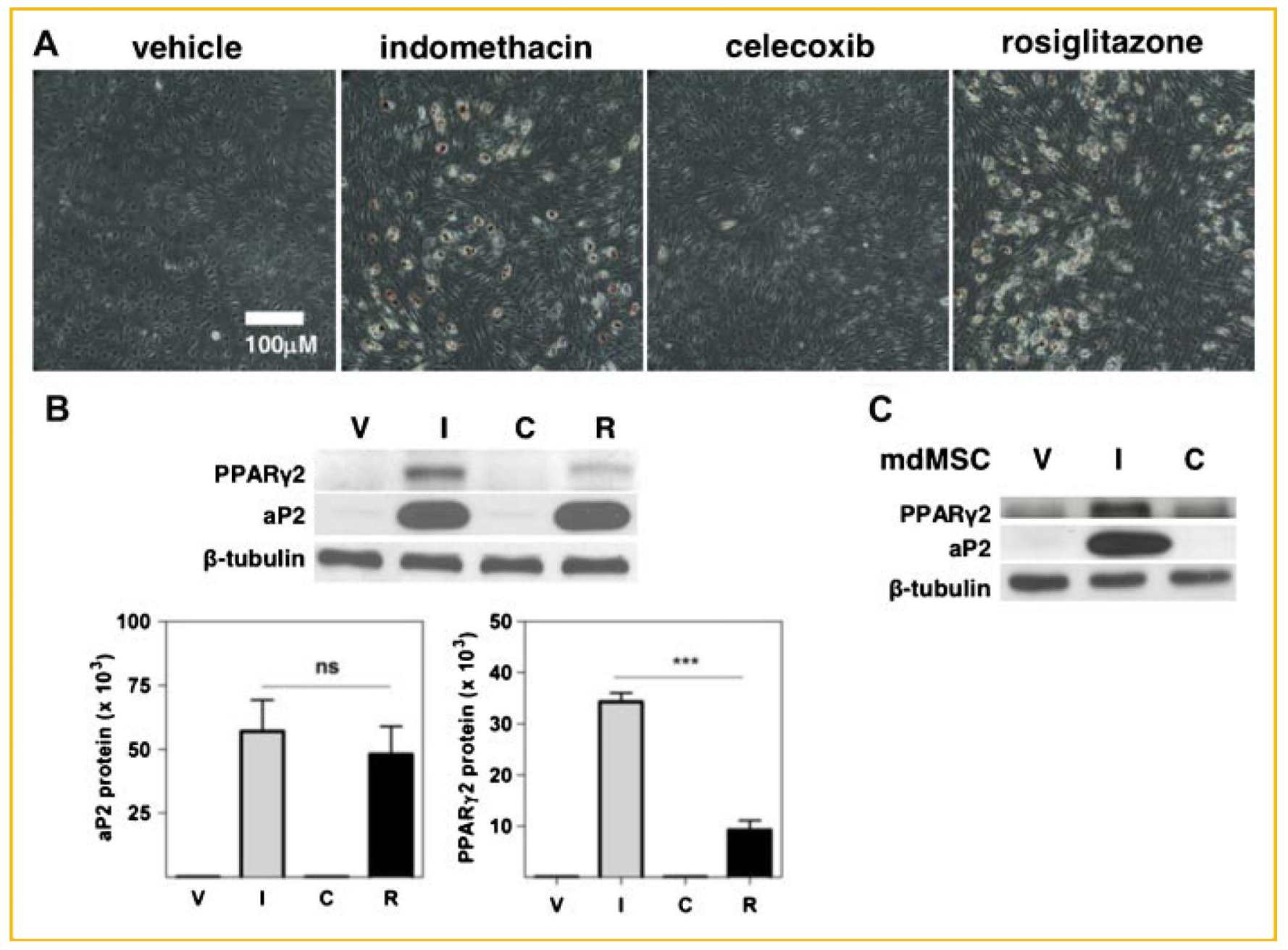

Fig. 1.

Indomethacin is a potent stimulator of adipogenesis in MSCs. A: Phase-contrast 10x Photomicrographs of $\mathrm{C} 3 \mathrm{H} 10 \mathrm{~T} 1 / 2$ stem cells cultured in adipogenic media \pm rosiglitazone $(10 \mu \mathrm{M})$, indomethacin $(10 \mu \mathrm{M})$ or celecoxib $(10 \mu \mathrm{M})$, day 3. B: Representative immunoblot analysis of C3H10T1/2 cells at day 3 in the presence of vehicle, indomethacin $(50 \mu \mathrm{M})$, celecoxib $(10 \mu \mathrm{M})$, or rosiglitazone $(10 \mu \mathrm{M})$. Protein expression normalized to $\beta$-tubulin $n=$ 2. C: Representative immunoblot of marrow-derived MSCs (mdMSC) at day 3 in the presence of vehicle, indomethacin $(50 \mu \mathrm{M})$, or celecoxib $(10 \mu \mathrm{M}) \mathrm{n}=3 ; * * * P<0.001$. 

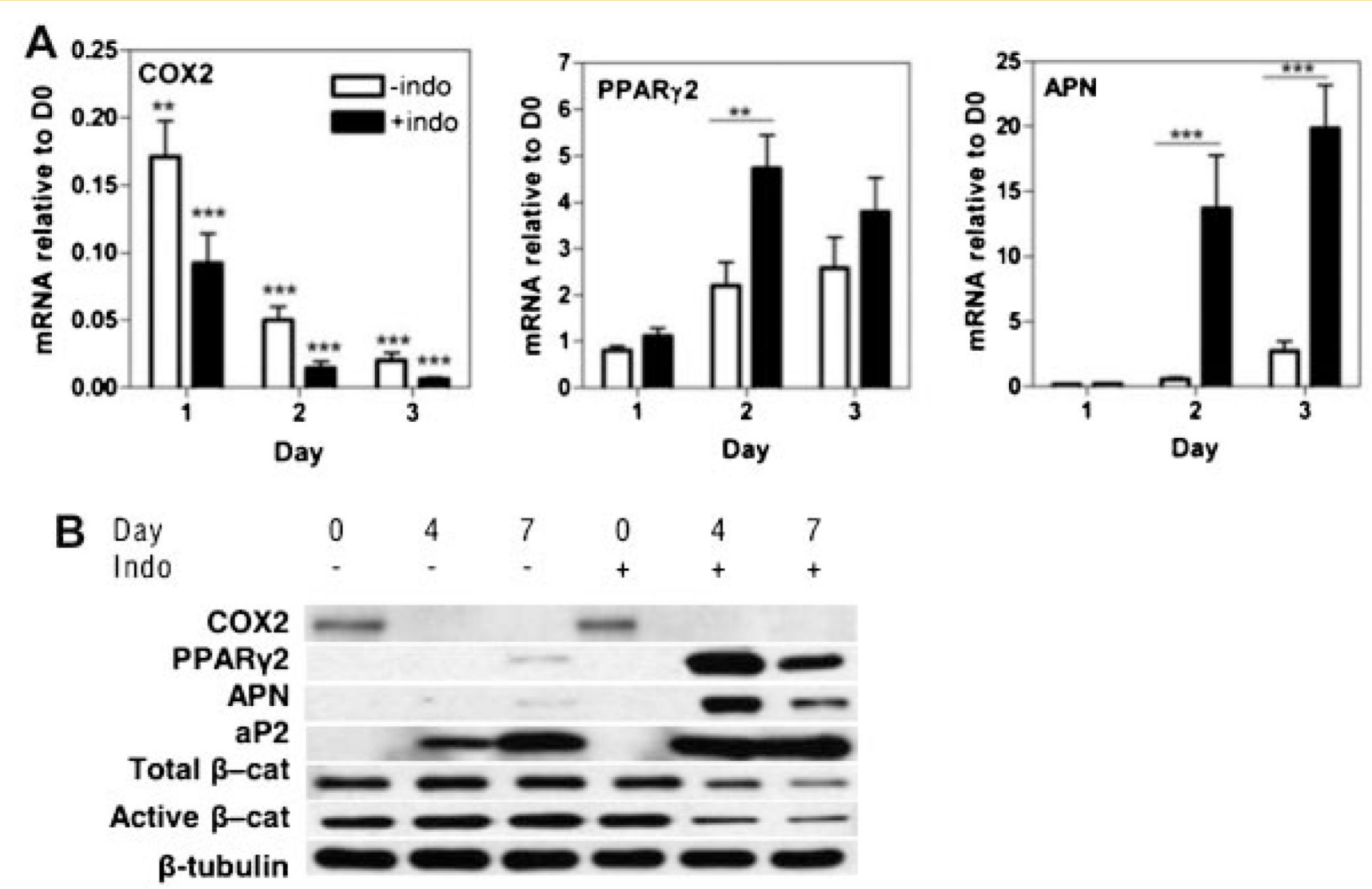

Fig. 2.

Indomethacin accelerates adipogenesis and degradation of b-catenin. A: RT-PCR analysis of mRNA harvested from C3H10T1/2 stem cells cultured in triplicate in adipogenic media \pm indomethacin $(50 \mu \mathrm{M})$ at indicated time points. COX2, PPAR $\gamma 2$, and adiponectin mRNA adjusted to $18 \mathrm{~S}$ and normalized to day zero controls. COX2 mRNA levels at each time point compared to day zero controls. B: Immunoblot analysis of C3H10T1/2 stem cells cultured in adipogenic media for indicated number of days \pm indomethacin $(50 \mu \mathrm{M})$ analyzed for $\mathrm{COX} 2$, PPAR $\gamma$, adiponectin (APN), aP2, total and active $\beta$-catenin. **P<0.01, *** $P<$ 0.001 . 


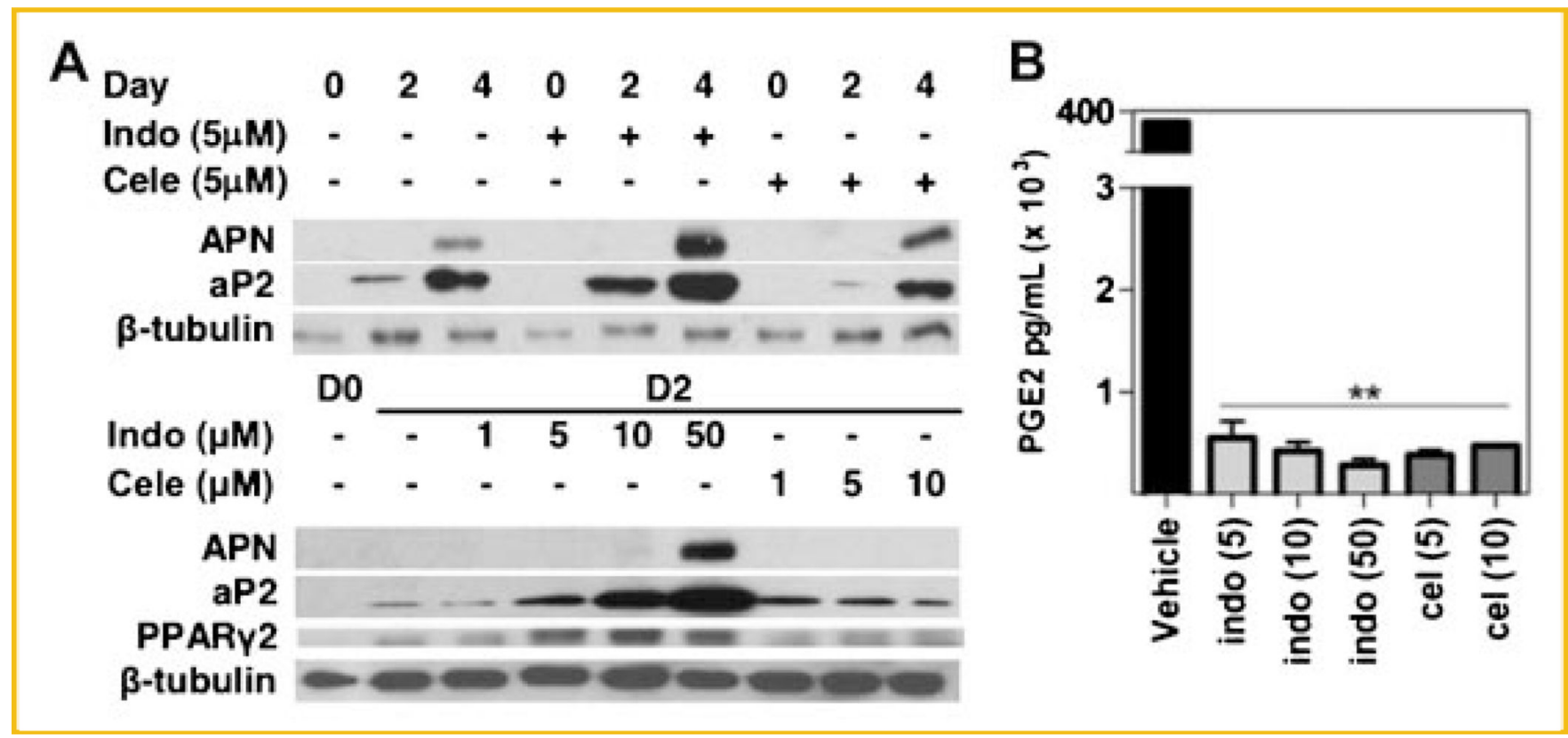

Fig. 3.

Celecoxib, a selective COX2 inhibitor, fails to replicate Indomethacin's adipogenic effect. A: Representative immunoblots of $\mathrm{C} 3 \mathrm{H} 10 \mathrm{~T} 1 / 2$ stem cells cultured in adipogenic media \pm indomethacin or celecoxib at indicated doses and time points analyzed for adiponectin (APN), aP2, and PPAR $\gamma$. B: C3HT101/2 stem cells were treated with arachidonic acid (25 $\mu \mathrm{M})$, indomethacin and celecoxib at indicated doses $(\mu \mathrm{M})$. Media PGE2 is reported; ** $P<$ 0.01 . 

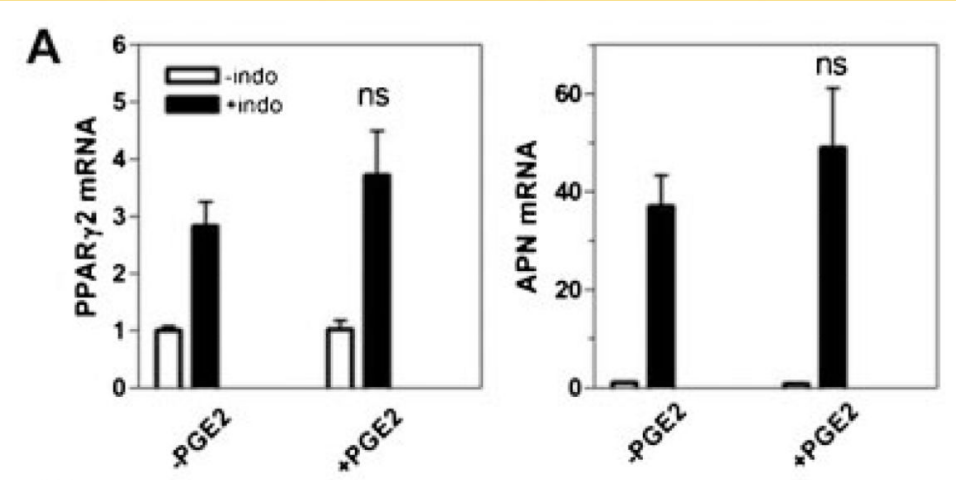

B

C
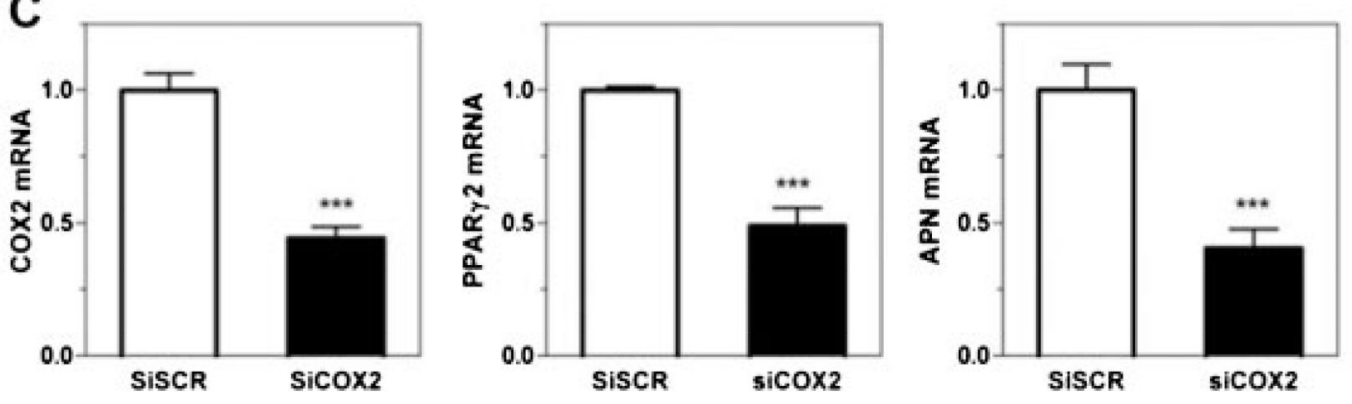

D

SIRNA SCR COX2

APN

aP2

$\beta$-tubulin

Fig. 4.

Indomethacin's adipogenic effect is independent of COX2 and PGE2. A: RT-PCR of C3H cells \pm indomethacin $(50 \mu \mathrm{M}), \pm$ PGE2 $(5 \mu \mathrm{M})$ expressed as fold increase over control. B: Western blot analysis of MSCs as in (A). C: MSCs in adipogenic media were transfected with siRNA to COX2 or siSCR (control). RT-PCR for COX2, PPAR $\gamma$, and adiponectin $(\mathrm{APN})$ was analyzed at $72 \mathrm{~h}$. Bars represent means \pm SEM, $\mathrm{n}=2$. D: Representative western blot analysis of MSCs transfected with siCOX2 versus siSCR at $72 \mathrm{~h}, \mathrm{n}=3 ; * * * P<0.001$. 
A

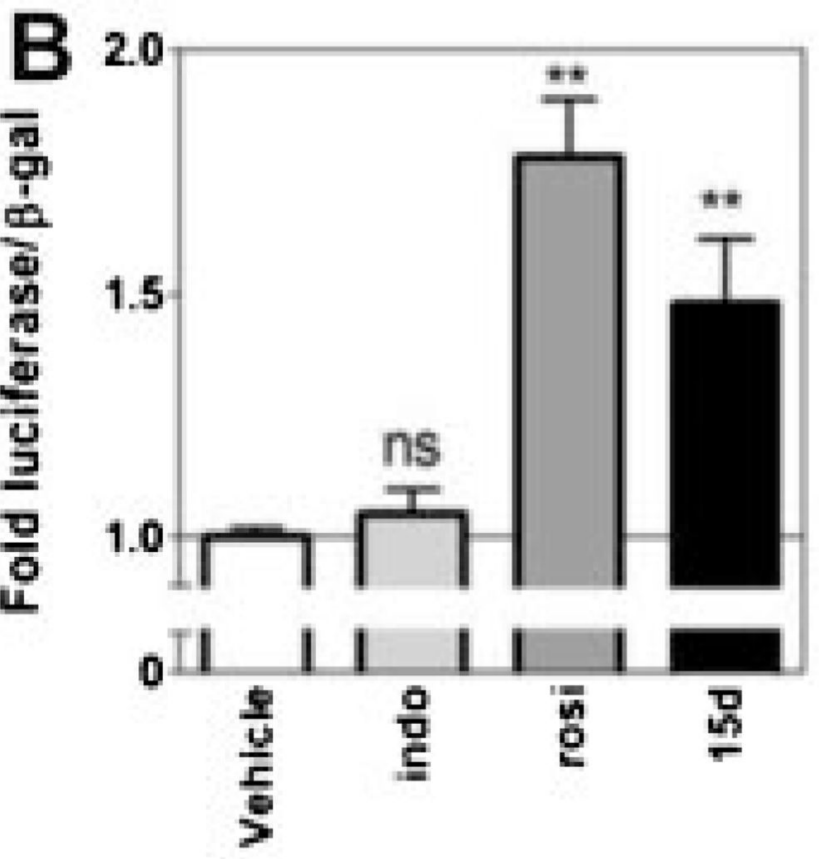

Fig. 5.

Indomethacin does not transactivate PPRE-luciferase construct. C3H10T1/2 cells were cotransfected with Flag-PPAR $\gamma 2$ and RXRa or empty vector control as well as the PPRELUC vector. $\beta$-galactosidase was used to control for transfection efficiency. A: Immunoblot analysis for Flag-PPAR $\gamma 2$ and PPAR $\gamma 224 \mathrm{~h}$ after transfection. B: Indomethacin $(50 \mu \mathrm{M})$, rosiglitazone $(20 \mu \mathrm{M}), 15 \mathrm{~d}-\mathrm{PGJ} 2(10 \mu \mathrm{M})$ or vehicle were added $24 \mathrm{~h}$ after transfection. PPRE-LUC reporter assay was performed $48 \mathrm{~h}$ later, $\mathrm{n}=3 ; * * P<0.01$. 


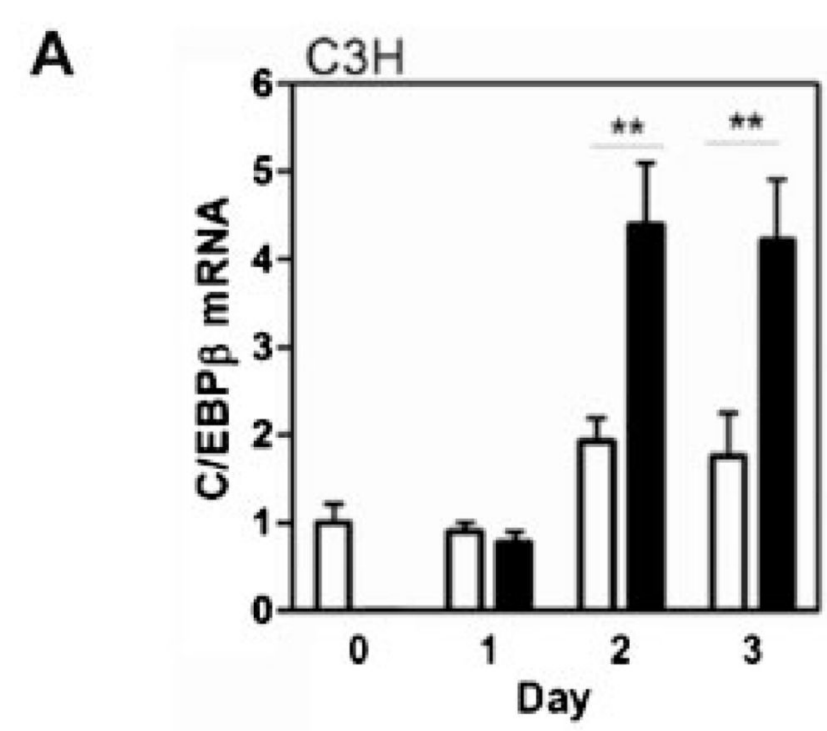

B

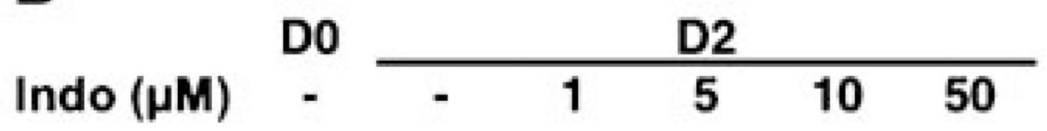

C/EBP- $\beta$ $\beta$-tubulin

Fig. 6.
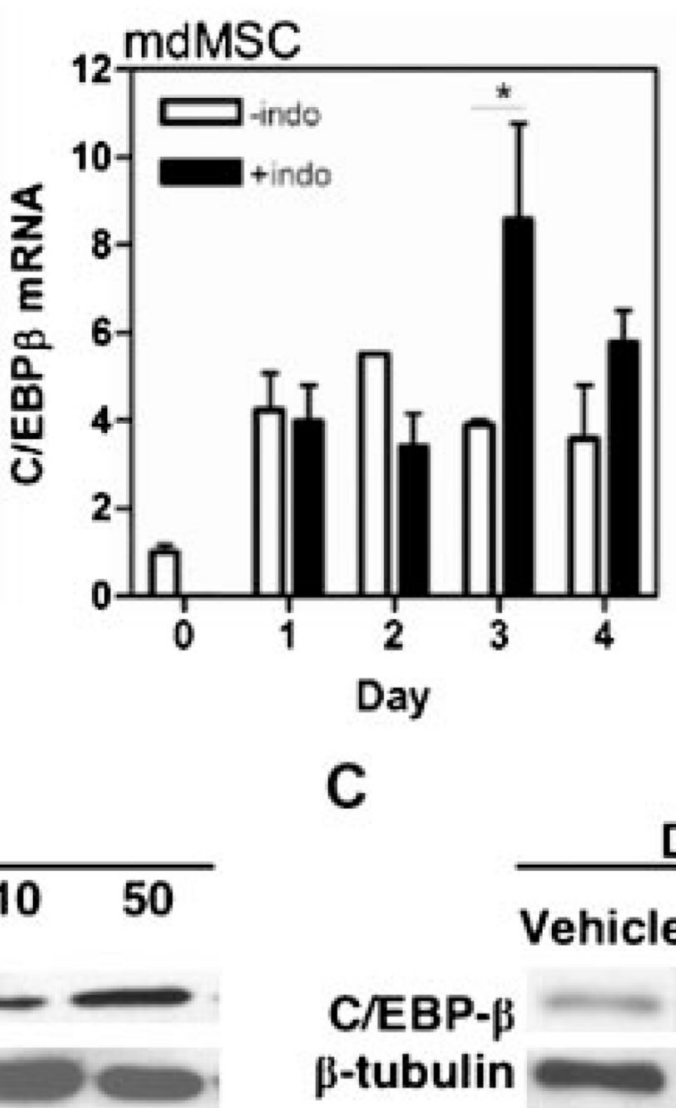

Indomethacin induces C/EBP $\beta$. A, left panel: C3H10T1/2 stem cells were cultured \pm indomethacin $(50 \mu \mathrm{M})$ at indicated time points and analyzed in triplicate by RT-PCR for C/ $\operatorname{EBP} \beta \mathrm{n}=3$. A right panel, mdMSCs were cultured \pm indomethacin $(50 \mu \mathrm{M})$ at indicated time points were analyzed by $\mathrm{RT}-\mathrm{PCR}$ for $\mathrm{C} / \mathrm{EBPb} \mathrm{n}=3$. B: Protein analysis confirms dose effect of indomethacin on $\mathrm{C} / \mathrm{EBP} \beta$ in $\mathrm{C} 3 \mathrm{H} 10 \mathrm{~T} 1 / 2$ stem cells. $\mathrm{C}$ : $\mathrm{C} / \mathrm{EBP} \beta$ protein induced by indomethacin $(50 \mu \mathrm{M})$ at day $3, \mathrm{n}=2 ; * * P<0.01$. 